\title{
Mucopolysaccharidosis Type IX
}

National Cancer Institute

\section{Source}

National Cancer Institute. Mucopolysaccharidosis Type IX. NCI Thesaurus. Code C129073.

An autosomal recessive lysosomal storage disease caused by mutation(s) in the HYAL1 gene, encoding hyaluronidase-1. It is characterized by short stature and hyaluronidase deficiency. 